\title{
Effects of the Non-Peptide Angiotensin II Receptor Antagonist TCV-116 on Systemic and Renal Hemodynamics in Dogs with Renal Hypertension
}

\author{
Katsuhiko Ito, Mie Shiomi, and Go Kito
}

\begin{abstract}
The effects of TCV-116, a new non-peptide angiotensin II receptor antagonist, on systemic and renal hemodynamics were studied in conscious normotensive and renal hypertensive (2-kidney, 1-clip Goldblatt type) dogs. When orally administered at 0.03 to $1.0 \mathrm{mg} / \mathrm{kg}, \mathrm{TCV}-116$ inhibited the pressor response to angiotensin II in conscious normotensive dogs in a dose-dependent fashion. The $\mathrm{IC}_{50}$ and $\mathrm{IC}_{100}$ values were $0.06 \mathrm{mg} / \mathrm{kg}$ and $0.86 \mathrm{mg} / \mathrm{kg}$, respectively. TCV-116 at doses of $0.3 \mathrm{mg} / \mathrm{kg}$ and $1.0 \mathrm{mg} / \mathrm{kg} \mathrm{dose-}$ dependently and persistently decreased systolic and diastolic blood pressure in both dogs with acute renal (hyperreninemic) and those with chronic renal (normoreninemic) hypertension. Even a high dose of TCV-116 $(10 \mathrm{mg} / \mathrm{kg}, \mathrm{p.o}$.) increased effective renal plasma flow without affecting blood pressure or glomerular filtration rate in normotensive dogs. Furthermore, even at this high dose, TCV-116 did not reduce effective renal plasma flow or glomerular filtration rate in dogs with renal hypertension despite marked reduction in systemic blood pressure. The angiotensin converting enzyme inhibitor enalapril (10 $\mathrm{mg} / \mathrm{kg}$, p.o.) had renal hemodynamic effects similar to those of TCV-116. These findings indicate that TCV-116 has potent hypotensive effects not only in dogs with acute renal hypertension but also in those with chronic renal hypertension, but does not appear to adversely affect renal hemodynamics. (Hypertens Res 1995; 18: 69-75)
\end{abstract}

Key Words: non-peptide angiotensin receptor antagonist, TCV-116, renal hypertensive dogs, renal hemodynamics

The renin-angiotensin system has long been known to play an important role in the pathophysiology of several circulatory disorders, and the use of angiotensin converting enzyme (ACE) inhibitors for the pharmacological blockade of this system in the treatment of hypertension and congestive heart failure has clearly proven beneficial (1). The great clinical success of ACE inhibitors has generated considerable interest in the development of specific pharmacological blockers of the renin-angiotensin system, and in particular, angiotensin II (AII) receptor antagonists. Recently, Kubo and co-workers (2) synthesized TCV-116, a highly potent AII receptor antagonist. In vitro studies by Shibouta et al. (3) have demonstrated that CV-11974, the active metabolite of TCV-116, is a potent non-peptide antagonist with high affinity, specificity and selectivity for the AII receptor (Type $\mathrm{AT}_{1}$ ). Furthermore, TCV-116 has been shown to decrease blood pressure in rats with various types of experimentally induced hypertension (4).

In the present study, we first examined the inhibitory effect of TCV-116 on the pressor response to AII in conscious normotensive dogs. We then ex-

amined the antihypertensive effect of TCV-116 in conscious dogs with acute or chronic renal hypertension, and finally evaluated the effect on renal hemodynamics of a overdose of TCV-116 in conscious dogs with renal hypertension.

Methods
1. Inhibitory Effect of TCV-116 on Pressor Re-
sponse to AII
Male beagle dogs weighing 10 to $13 \mathrm{~kg}$ were pre-
pared for blood pressure recording as follows. They
were first anesthetized with sodium pentobarbital
$(30 \mathrm{mg} / \mathrm{kg}$, i.v.). One catheter was then positioned
in the lower abdominal aorta via the femoral artery
for measurement of systemic blood pressure, and
another was positioned in the inferior vena cava via
the femoral vein for AII administration. Each
catheter was led through a subcutaneous tunnel on
the animal's back and secured to the skin between
the scapulae. The dogs were permitted an approx-
imately 5-day period for recovery from surgery. Af-
ter establishing a basal pressor response to AII
$(0.1 \mu \mathrm{g} / \mathrm{kg}, \mathrm{i} . \mathrm{v}$.$) , TCV-116 was administered orally.$

From the Department III, Drug Safety Research Laboratories, Pharmaceutical Development Division, Takeda Chemical Industries, Japan.

Address for Reprints: Katsuhiko Ito, Ph.D., Department III, Drug Safety Research Laboratories, Pharmaceutical Development Division, Takeda Chemical Industries, Juso, Yodogawa-ku, Osaka 532, Japan.

Received June 16, 1994; accepted in revised form September 2, 1994. 
Thereafter, AII was injected repeatedly at $1,2,5$, 7, 10 and $24 \mathrm{~h}$ after TCV-116 treatment. Pressor responses to AII before and after the administration of TCV-116 were determined, and the inhibitory effect of drugs on the pressor response was evaluated as percent change in pressor response. The $\mathrm{IC}_{50}$ and $\mathrm{IC}_{100}$ values were calculated from the area over the time-effect curve from 0 to $10 \mathrm{~h}$.

\section{Antihypertensive Effect}

Male beagle dogs weighing 12 to $13 \mathrm{~kg}$ were used. They were first anesthetized with sodium pentobarbital $(30 \mathrm{mg} / \mathrm{kg}$, i.v.). The right renal artery was then exposed through a flank incision and was constricted with a silver clip to reduce renal arterial blood flow to $40 \%$ of the initial value. Dogs were tested 3 days after surgery as models of acute phase (hyperreninemic) hypertension. More than 8 weeks after initiation of renal arterial constriction, those dogs with a mean blood pressure of $140 \mathrm{mmHg}$ or higher while conscious were used as models of chronic phase (normoreninemic) hypertension. Dogs were trained to sit quietly in their cage. Blood pressure and heart rate were measured indirectly with an electro-sphygmomanometer (Narco, RE300) consisting of an inelastic cuff containing an inflatable rubber bag. The sphygmomanometer cuff was applied to the foreleg. Measurements were made $0.5,1,2,3,5,7,10$ and $24 \mathrm{~h}$ after oral administration of drugs.

Plasma renin activity was measured by radioimmunoassay using a commercially available kit (Renin Riabead, Dinabot).

\section{Renal Hemodynamic Effect of TCV-116 and Enalapril}

Normotensive and chronic renal hypertensive dogs were used. The effective renal plasma flow (ERPF) and glomerular filtration rate (GFR) were measured by the single-injection technique using para-aminohippuric acid (PAH) and iothalamate by the method of Fujiwara et al. (5). In brief, a mixture of $\mathrm{PAH}$ and iothalamate $(30 \mathrm{mg} / \mathrm{kg})$ was injected intravenously, and blood samples were obtained 0,5 , $10,20,30,60,90,120$ and 180 min later. The plasma concentrations of $\mathrm{PAH}$ and iothalamate were determined by reversed-phase high performance liquid chromatography (column: YMC-Pack A-312, HPLC system: Hitachi Model L-6200). In brief, $100 \mu \mathrm{l}$ of plasma was mixed with $5 \%$ perchloric acid and centrifuged. The supernatant was neutralized with $1 \mathrm{~N} \mathrm{NaOH}$, and a $50 \mu \mathrm{l}$ aliquot was subjected to HPLC. The sample was eluted with $0.1 \mathrm{M}$ $\mathrm{NaH}_{2} \mathrm{PO}_{4} /$ methanol $(85: 15)$ at a flow rate of 1.0 $\mathrm{ml} / \mathrm{min}$, and the optical density was read at a wavelength of $245 \mathrm{~nm}$. The retention times of PAH and iothalamate were approximately 5 and $8 \mathrm{~min}$, respectively. ERPF and GFR were calculated as follows:

$$
\begin{aligned}
\mathrm{ERPF} & =Q_{\mathrm{PAH}} / \mathrm{AUC}_{\mathrm{PAH}} \\
\mathrm{GFR} & =Q_{\mathrm{IOT}} / \mathrm{AUC}_{\mathrm{IOT}}
\end{aligned}
$$

where $Q_{\mathrm{PAH}}$ and $Q_{\text {IOT }}$ were the total amounts of $\mathrm{PAH}$ and iothalamate injected, and $\mathrm{AUC}_{\mathrm{PAH}}$ and $\mathrm{AUC}_{\mathrm{IOT}}$ were the areas under the plasma concentration-time curves of these indicators from 0 to $180 \mathrm{~min}$.

After measurement of blood pressure, ERPF and GFR, TCV-116 or enalapril was administered orally, and blood pressure, ERPF and GFR were measured 2 and $24 \mathrm{~h}$ later.

All values were expressed as means \pm SEM. Bonferroni's test for paired values was used to compare measurements before and after treatment. These analyses were performed using the SAS GLM procedure (6). $p$ Values below 0.05 were considered to indicate statistical significance.

\section{Results}

1. Inhibitory Effect of TCV-116 on Pressor Response to AII

The basal pressor responses to AII in groups treated with $0.003,0.03,0.3$ and $1.0 \mathrm{mg} / \mathrm{kg}$ of TCV-116 were $48.3 \pm 3.7,44.2 \pm 4.0,47.3 \pm 4.4$ and $37.8 \pm 3.5$ $\mathrm{mmHg}$, respectively. There was no difference among these groups. TCV-116 attenuated the pressor response to AII in a dose-dependent fashion (Fig.1). Maximum inhibition at $0.03 \mathrm{mg} / \mathrm{kg}$ of TCV116 was observed 3 to $5 \mathrm{~h}$ after administration. At this dose, inhibition rates were $40 \pm 5.0 \%$ at $3 \mathrm{~h}$ and $50 \pm 9.8$ at $5 \mathrm{~h}$. At $0.3 \mathrm{mg} / \mathrm{kg}$, the rate of inhibition was $88.7 \pm 2.9 \%$ at $3 \mathrm{~h}$, and the inhibitory effect lasted for up to $10 \mathrm{~h}$. At $1.0 \mathrm{mg} / \mathrm{kg}$, the pressor response to AII was completely eliminated for $10 \mathrm{~h}$. The calculated $\mathrm{IC}_{50}$ and $\mathrm{IC}_{100}$ values were 0.06 $\mathrm{mg} / \mathrm{kg}$ and $0.86 \mathrm{mg} / \mathrm{kg}$, respectively (Fig. 2).

TCV-116 at $1 \mathrm{mg} / \mathrm{kg}$ did not affect the pressor response to norepinephrine or the depressor response to bradykinin (data not shown).

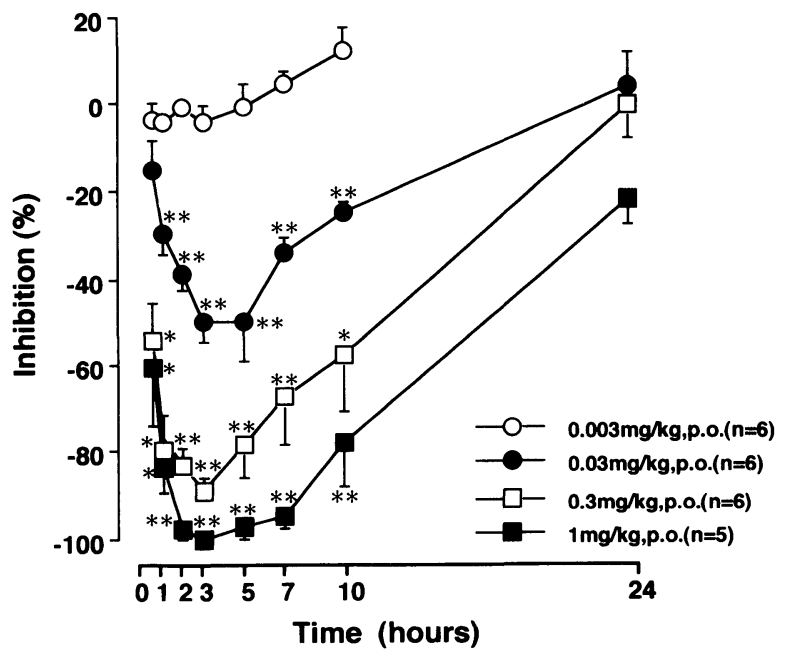

Fig. 1. Effect of TCV-116 on the pressor response to AII. $T C V-116$ was given orally to conscious beagle dogs, and the change in the pressor response to AII $(0.1 \mu \mathrm{g} / \mathrm{kg}, \mathrm{i.v}$. was observed. Each point represents the mean $\pm S E M$. Significant differences between the baseline value and experimental period: ${ }^{*} \mathrm{p}<0.05 ;{ }^{*} \mathrm{p}<0.01$. Details are described in the text. 
2. Antihypertensive Effect of TCV-116 in Dogs with Renal Hypertension

Acute phase of hypertension: As shown in Fig. 3, dogs tested 3 days after surgery had high systolic $(203.1 \pm 2.5 \mathrm{mmHg})$ and diastolic (109.1 \pm 0.9 $\mathrm{mmHg}$ ) blood pressures and increased PRA of approximately $5 \mathrm{ngAI} / \mathrm{ml} / \mathrm{h}$. Basal heart rate was $87.2 \pm 5.5$ beats $/ \mathrm{min}$. There were no differences in basal blood pressure or heart rate among the 0.1 , 0.3 and $1.0 \mathrm{mg} / \mathrm{kg}$ TCV-116 groups.

TCV-116 reduced both systolic and diastolic blood pressures in a dose-dependent fashion at 0.3 to $1.0 \mathrm{mg} / \mathrm{kg}$ (Fig. 4). TCV-116 administered orally at $0.3 \mathrm{mg} / \mathrm{kg}$ reduced systolic and diastolic blood pressures by 27 and $29 \mathrm{mmHg}$, respectively; these effects lasted for $7 \mathrm{~h}$ after administration. TCV-116 administered orally at $1 \mathrm{mg} / \mathrm{kg}$ markedly reduced both systolic and diastolic blood pressures by about $45 \mathrm{mmHg}$, and its hypotensive effect lasted for $10 \mathrm{~h}$. Heart rate was not affected by TCV-116.

Chronic phase of hypertension: As shown in Fig. 3 , dogs tested 1 to 2 months after surgery had high systolic $(207.8 \pm 3.8 \mathrm{mmHg})$ and diastolic $(115 \pm 1.6$ $\mathrm{mmHg}$ ) blood pressures, but PRA had normalized to 1 to $2 \mathrm{ngAI} / \mathrm{ml} / \mathrm{h}$. There were no differences in basal blood pressure or heart rate among the 0.1, 0.3 and $1.0 \mathrm{mg} / \mathrm{kg}$ TCV-116 groups.

TCV-116 at doses of 0.3 to $1.0 \mathrm{mg} / \mathrm{kg}$ reduced blood pressure in a dose-dependent fashion (Fig. 5). TCV-116 administered orally at $0.3 \mathrm{mg} / \mathrm{kg}$ reduced both systolic and diastolic blood pressures by about $30 \mathrm{mmHg}$, and its hypotensive effect lasted for $7 \mathrm{~h}$. $\mathrm{TCV}-116$ administered orally at $1 \mathrm{mg} / \mathrm{kg}$ reduced both systolic and diastolic blood pressures by about $50 \mathrm{mmHg}$, and its hypotensive effect lasted for $10 \mathrm{~h}$. Heart rate was not affected by TCV-116.

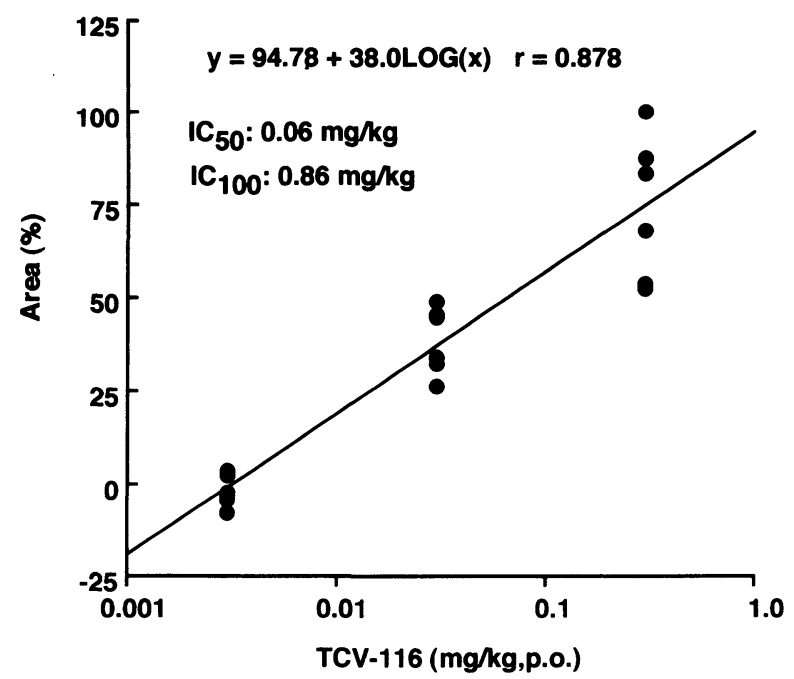

Fig. 2. The relationship between the area (the area over the inhibitory effect-time curve shown in Fig. 1) and dose given to the dogs. The $I C_{50}$ and $I C_{100}$ values of TCV-116 on the pressor response to $A I I(0.1 \mu g / k g, i . v$.$) were$ calculated.

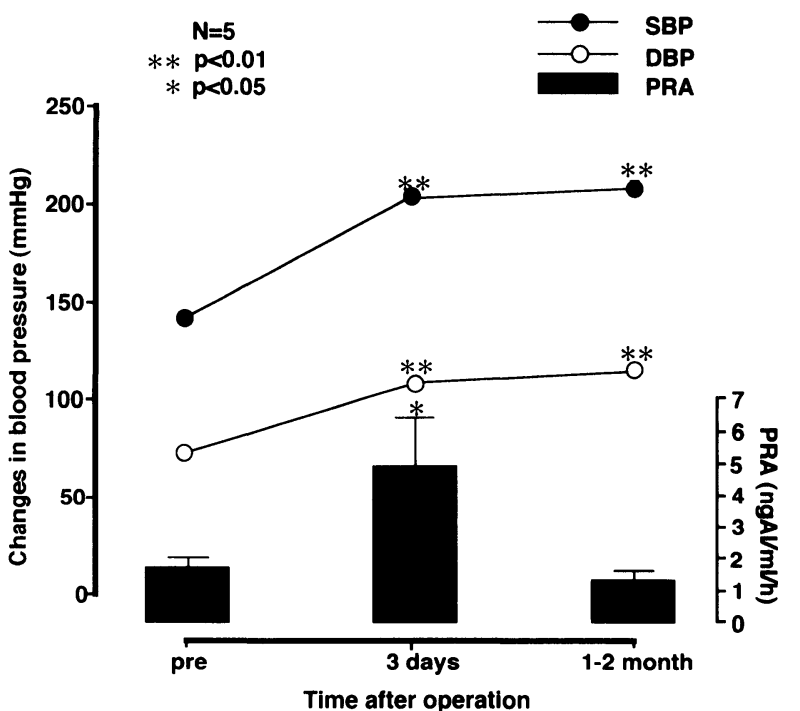

Fig. 3. Changes in blood pressure and plasma renin activity after renal arterial stenosis in beagle dogs. SBP, systolic blood pressure; DBP, diastolic blood pressure; PRA, plasma renin activity. Significant differences between the baseline value and experimental period: ${ }^{*} \mathrm{p}<0.05$, ${ }^{* *} \mathrm{p}<0.01$. Details are described in the text.

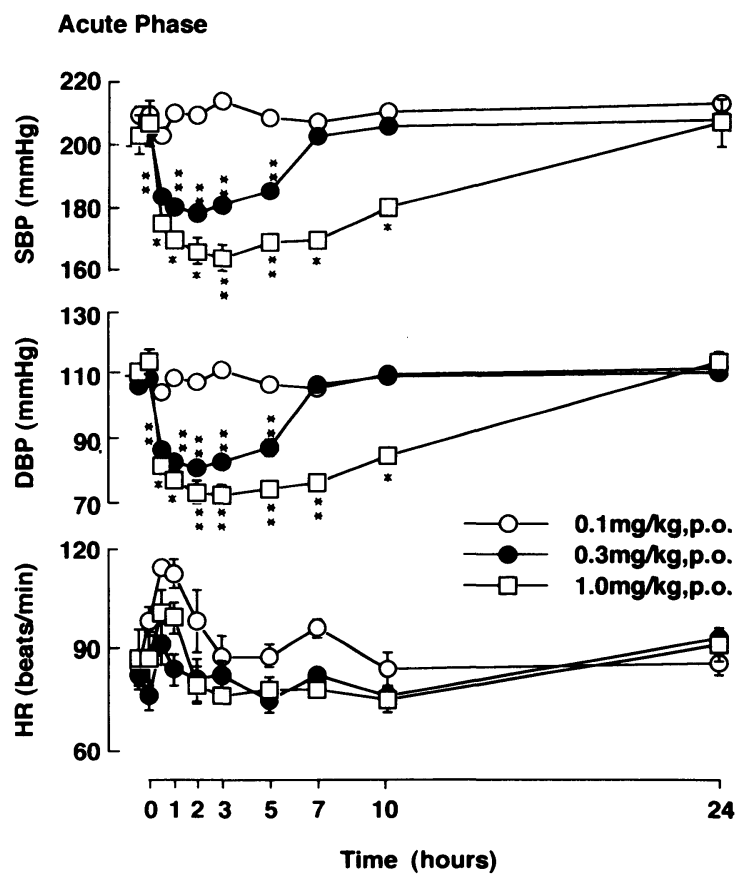

Fig. 4. The hypotensive effect of TCV-116 on systolic blood pressure $(S B P)$, diastolic blood pressure $(D B P)$ and heart rate $(H R)$ in acute 2-kidney, 1-clip renal hypertensive dogs. TCV-116 was given orally. Each point represents the mean $\pm S E M$ of 4 dogs. Significant differences between the baseline value and experimental period: ${ }^{*} \mathrm{p}<0.05$; ${ }^{* *} \mathrm{p}<0.01$. Details are described in the text. 
3. Effects of TCV-116 and Enalapril on Renal Hemodynamics

Basal blood pressure, ERPF and GFR in normotensive dogs in this study were similar in the control, TCV-116 and enalapril groups. TCV-116 administered orally at $10 \mathrm{mg} / \mathrm{kg}$ had no effect on mean blood pressure, but significantly increased ERPF. It had no effect on GFR (Fig.6). Enalapril at 10 $\mathrm{mg} / \mathrm{kg}$ also had no effect on mean blood pressure or GFR, but significantly increased ERPF.

In dogs with chronic renal hypertension, the basal mean blood pressure, ERPF and GFR were similar in all three treatment groups. TCV-116 administered orally at $10 \mathrm{mg} / \mathrm{kg}$ reduced mean blood pressure 3 to $5 \mathrm{~h}$ later by about $45 \mathrm{mmHg}$, but had no effect on ERPF or GFR (Fig.7). Enalapril administered orally at $10 \mathrm{mg} / \mathrm{kg}$ reduced mean blood pressure to the same extent as TCV-116 did, and also had no effect on ERPF or GFR (Fig.7).

\section{Discussion}

Our findings show that TCV-116, a non-peptide AII receptor antagonist, suppresses in a dose-dependent fashion the pressor response to AII in conscious normotensive dogs and reduces in a dose-dependent fashion blood pressure not only in conscious dogs with acute renal hypertension but also in those with chronic renal hypertension. TCV-116 had no effect on renal plasma flow or GFR even at high doses in

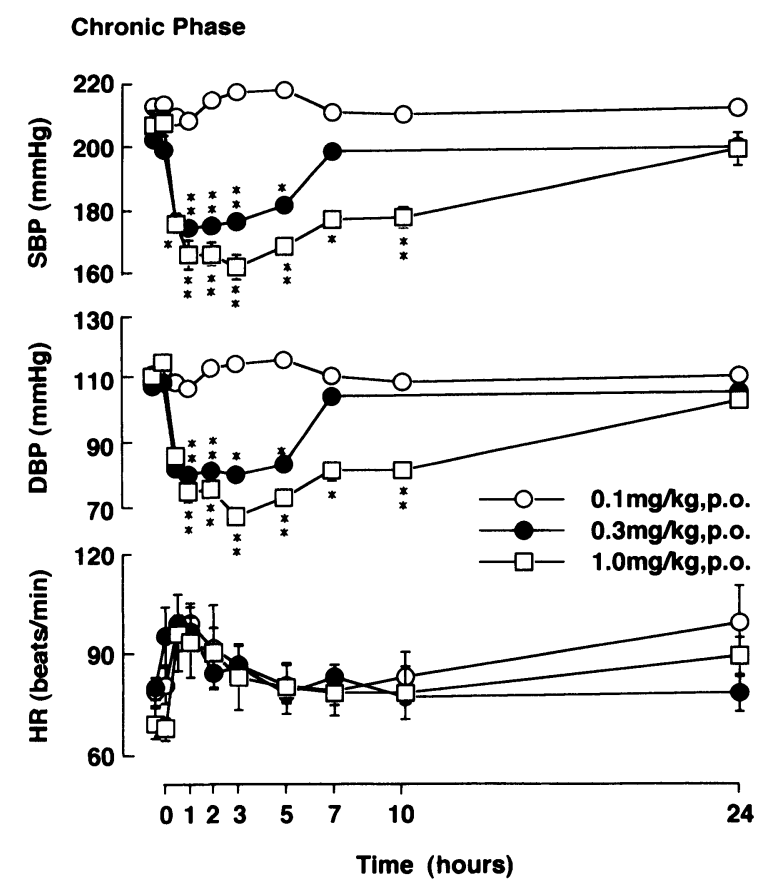

Fig. 5. The hypotensive effect of TCV-116 on systolic blood pressure $(S B P)$, diastolic blood pressure $(D B P)$ and heart rate $(H R)$ in chronic 2-kidney, 1-clip renal hypertensive dogs. TCV-116 was given orally. Each point represents the mean $\pm S E M$ of 4 dogs. Significant differences between the baseline value and experimental period: ${ }^{*} \mathrm{p}<$ $0.05 ;{ }^{* *} \mathrm{p}<0.01$. Details are described in the text. dogs with renal hypertension.

A dose of $0.3 \mathrm{mg} / \mathrm{kg}$ TCV-116 maximally inhibited pressor responses to AII, and continued to have an hypertensive effect for $10 \mathrm{~h}$. Calculated $\mathrm{IC}_{50}$ and $\mathrm{IC}_{100}$ values were 0.06 and $0.86 \mathrm{mg} / \mathrm{kg}$, respectively. The plasma concentration of CV-11974, the active metabolite of TCV-116, was measured after oral administration of $0.06 \mathrm{mg} / \mathrm{kg}\left(\mathrm{IC}_{50}\right.$ value) TCV-116. The time-concentration profile is shown in Fig.8. Even $8 \mathrm{~h}$ after administration, the concentration of CV-11974 in plasma was approximately $0.3 \mathrm{ng} / \mathrm{ml}\left(0.68 \times 10^{-9} \mathrm{M}\right)$. These findings clearly show that the inhibitory effect of TCV-116 on the pressor responses to AII is due to blockade of vascular AII receptors. Furthermore, TCV-116 at 1 $\mathrm{mg} / \mathrm{kg}$, which completely inhibited the pressor response to AII, did not affect the response to norepinephrine or the depressor response to bradykinin. These findings indicate that TCV-116 had a potent and selective inhibitory effect on the vascular AII receptor in the dogs tested in this study.

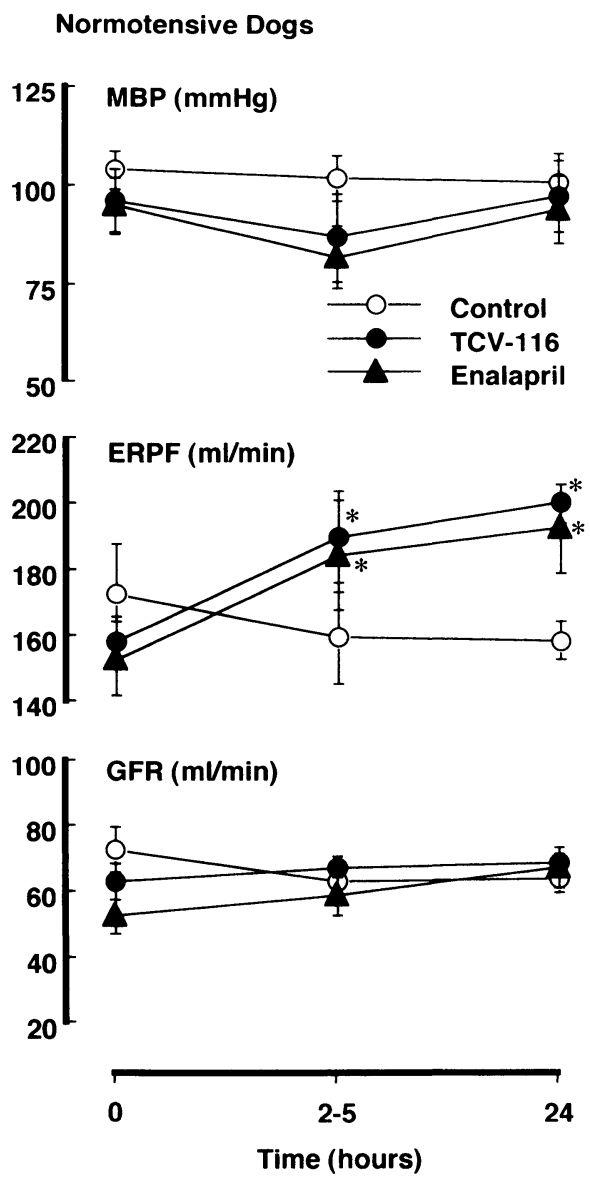

Fig. 6. Renal hemodynamic effects of TCV-116 and enalapril on mean blood pressure $(M B P)$, effective renal plasma flow (ERPF) and glomerular filtration rate (GFR) in normotensive dogs. TCV-116 and enalapril were given orally at a dose of $10 \mathrm{mg} / \mathrm{kg}$. Each point represents the mean $\pm S E M$ of 4 dogs. Significant differences between the baseline value and experimental period: ${ }^{*} \mathrm{p}<0.05$. Details are described in the text. 


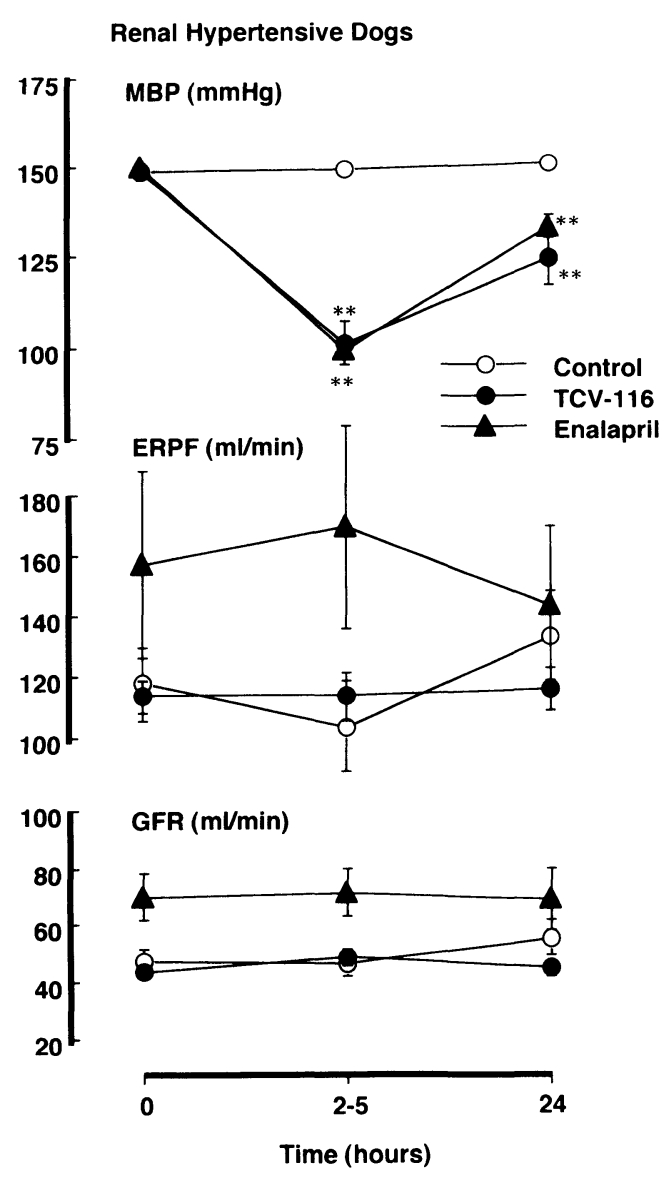

Fig. 7. Renal hemodynamic effects of TCV-116 and enalapril on mean blood pressure (MBP), effective renal plasma flow (ERPF) and glomerular filtration rate (GFR) in chronic renal hypertensive dogs. TCV-116 and enalapril were given orally at a dose of $10 \mathrm{mg} / \mathrm{kg}$. Each point represents the mean $\pm S E M$ of 4 dogs. Significant differences between the baseline value and experimental period: ${ }^{* *} \mathrm{p}<0.01$. Details are described in the text.

Following these findings, the antihypertensive effect of TCV-116 was evaluated in 2-kidney, 1-clip Goldblatt hypertensive dogs in which the renal artery had been constricted with a silver clip to reduce renal blood flow by about $60 \%$. PRA 2 to 3 days after surgery was significantly elevated and accompanied by an increase in systemic blood pressure. We used these dogs as a model of acute phase (hyperreninemic) hypertension. TCV-116 significantly reduced both systolic and diastolic blood pressure in a dose-dependent fashion. The hypotensive effect at $0.3 \mathrm{mg} / \mathrm{kg}$ lasted for $5 \mathrm{~h}$, while at 1 $\mathrm{mg} / \mathrm{kg}$ it lasted for $10 \mathrm{~h}$. These findings indicate that TCV-116 reduced blood pressure via peripheral vasodilation by antagonizing elevated levels of circulating AII in dogs with acute renal hypertension.

In dogs with chronic renal hypertension, TCV-116 reduced both systolic and diastolic blood pressures, and the blood pressure profile over time was very similar to that observed for the acute renal hypertensive model. In our dogs with chronic renal

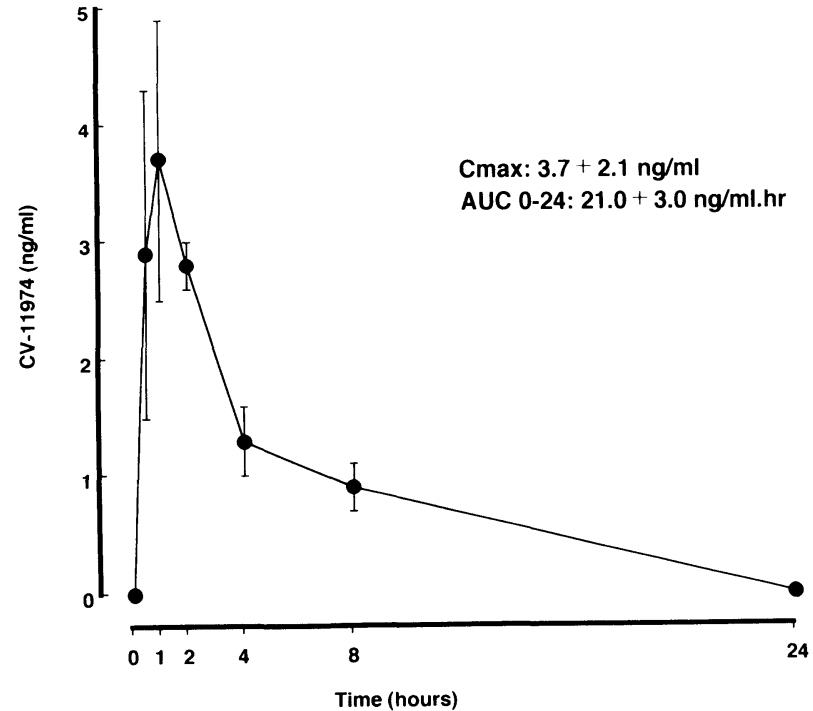

Fig. 8. Changes in plasma $C V-11974$ concentration after oral administration of TCV-116 to dogs. TCV-116 was given at a dose of $0.06 \mathrm{mg} / \mathrm{kg}$ (IC $C_{50}$ value), and the plasma concentration of $C V-11974$, the active metabolite of TCV116, was measured.

hypertension, PRA returned to basal level, even though blood pressure remained high. This is consistent with the findings of previous studies $(7,8)$. Miyazaki et al. (8) reported that increased vascular AII production plays a role in maintaining chronic renal hypertension. The reduction in blood pressure achieved by ACE inhibitors in dogs with chronic renal hypertension is thought to be due to the inhibitory effect of these agents on increased activity of the renin-angiotensin system in vascular tissue (9). AII is known to induce vasoconstriction by direct stimulation of vascular AII receptors. There is evidence for the existence of AII-induced pre-junctional facilitatory effects in peripheral noradrenergic nerve terminals of various tissues including the adrenal gland, heart, blood vessels and kidney (10). In theory, several AII-generating pathways might participate in vascular AII production (11-13). Angiotensin I may be converted to AII by endothelial ACE, extra-endothelial ACE, and other enzymes in the vascular wall, as is the case for the chymostatin-sensitive AII generating enzyme (11). Accordingly, it seems likely that TCV-116 reduced blood pressure by antagonizing local AII produced within the vascular wall in dogs with chronic renal hypertension.

Disturbances of autoregulation of renal blood flow including shifts to the right in the lower limit of the curve have been described for several animal models of hypertension as well as for patients with hypertension (14-19). Furthermore, the degree of disturbance of renal autoregulation has been shown to be related to the severity of hypertension (14). It is therefore important that the renal effects of antihypertensive agents be evaluated. We examined the effects on renal hemodynamics of $10 \mathrm{mg} / \mathrm{kg}$ of 
TCV-116, which was considered to be an overdose, in normotensive dogs and in dogs with renal hypertension. The single injection technique using $\mathrm{PAH}$ and iothalamate was employed for measurement of ERPF and GFR. This method has been used for measurement of renal hemodynamics because its results correlate well with those of the standard clearance method $(5,20)$. TCV-116 at a dose of 10 $\mathrm{mg} / \mathrm{kg}$ significantly increased ERPF, but had no effect on systemic blood pressure or GFR in normotensive dogs. The same dose of TCV-116 had no effect on cardiac output in conscious normotensive dogs as measured by the thermodilution technique (data not shown). Thus, in these dogs TCV-116 induced renal vasodilation without affecting total peripheral resistance. Chan et al. (21) reported that intravenous infusion of DuP 753 increased renal blood flow and GFR in anesthetized dogs without affecting blood pressure, consistent with the results of the present study. These findings taken together suggest that TCV-116 has a renovasodilative effect in normotensive dogs.

In dogs with renal hypertension, TCV-116 at 10 $\mathrm{mg} / \mathrm{kg}$ reduced mean blood pressure by about 50 $\mathrm{mmHg}$; the hypotensive effect of this dose lasted 24 $h$, but no effect on ERPF or GFR was noted. AII receptor antagonists usually maintain autoregulation of renal blood flow, but not that of GFR (22). We therefore measured the lower limit of autoregulation of renal blood flow in anesthetized dogs. This value was about $75 \mathrm{mmHg}$ in normotensive dogs, consistent with that determined by Abe et al. (23). In the dogs with renal hypertension tested in the present study, the lower limit of autoregulation was about $100 \mathrm{mmHg}$ (data not shown). These findings suggest that TCV-116 did not reduce blood pressure (renal perfusion pressure) below the lower limit of autoregulation of renal blood flow in dogs with renal hypertension. Bovee et al. (24) similarly found that intravenous administration of the AII receptor antagonist DuP 753 increased renal blood flow and GFR and decreased blood pressure in spontaneously hypertensive dogs. These findings taken together demonstrate the beneficial effects on renal hemodynamics of AII antagonists. TCV-116 maintained renal blood flow and GFR despite a reduction in systemic blood pressure in dogs with renal hypertension. TCV-116 may thus have beneficial effects on renal function and hemodynamics in patients with essential hypertension.

Because blockade of the renin-angiotensin system with ACE inhibitor(s) has been proven to be beneficial in the treatment of hypertension and congestive heart failure, it seems likely that TCV- 116, given its beneficial renal hemodynamic effects, will also prove useful for the treatment of these disorders.

\section{References}

1. Kostis JB: Angiotensin converting enzyme inhibitors in hypertension. Cardiovasc Drug Rev 1989; 7: 173-176.

2. Kubo K, Kohara Y, Imamiya E, et al: Nonpeptide angiotensin II receptor antagonists. Synthesis and biological activity of benzimidazole carboxylic acids. J Med Chem 1993; 36: 2182-2195.

3. Shibouta Y, Inada Y, Ojima M, et al: Pharmacological profile of a highly potent and long-acting angiotensin II receptor antagonist, 2-ethoxy-1-[[2'(1H-tetrazol-5-yl) biphenyl-4-yl] methyl]-1H-benzimidazole-7-carboxylic acid (CV-11974) and its prodrug, ( \pm )-1-(cyclohexylcarbonyloxy) ethyl 2-ethoxy1-[[2'- (1H-tetrazol-5-yl)biphenyl-4-yl] methyl]-1H-benzimidazole-7-carboxylate (TCV-116). J Pharmacol Exp Ther 1993; 266: 114-120.

4. Inada Y, Wada T, Shibouta Y, et al: Antihypertensive effects of a highly potent and long-acting angiotensin II subtype-1 receptor antagonist, $( \pm)-1-$ (cyclohexylcarbonyloxy) ethyl 2-ethoxy-1-[[2'- $(1 \mathrm{H}-$ tetrazol-5-yl)biphenyl-4-yl] methyl]-1H- benzimidazole7-carboxylate (TCV-116), in various hypertensive rats. J Pharmacol Exp Ther 1994; 268: 1540-1547.

5. Isaka Y, Fujiwara Y, Yamamoto S, et al: Modified plasma clearance technique using nonradioactive iothalamate for measuring GFR. Kidney Int 1992; 42: 1006-1011.

6. SAS Institute Inc. SAS user's guide: Statistics, Version 5 Edition, NC, SAS Institute Inc. Cary, 1985.

7. Miyazaki M, Okamura T, Okunishi $\mathrm{H}$, Toda $\mathrm{N}$ : Possible role of vascular angiotensin converting enzyme in the genesis of hypertension. Clin Exp Hypertens 1987; A9: 435-440.

8. Miyazaki M, Okamura $\mathrm{T}$, Okunishi $\mathrm{H}$, Toda $\mathrm{N}$ : Vascular angiotensin converting enzyme in the development of renal hypertension. $J$ Cardiovasc Pharmacol 1986; 8 (suppl 10): S58-S61.

9. Nishimura K, Miyazaki M, Okunishi H, Toda N: Hypotensive effect of SA-446, an angiotensin converting enzyme inhibitor, in 2-kidney, 1-clip renal hypertensive and normotensive dogs. Jpn J Pharmacol 1987; 48: 379-387.

10. Dzau VJ, Pratt RE: Renin- angiotensin system, in HA Fozzard et al (eds). The heart and cardiovascular system Raven Press, 1992, New York, pp 1817-1849.

11. Okunishi $\mathrm{H}$, Miyazaki M, Okamura T, Toda $\mathrm{N}$ : Different distribution of two type of angiotensin IIgenerating enzyme in the aortic wall. Biochem Biophys Res Commun 1987; 149: 1186-1192.

12. Gondo $\mathrm{M}$, Maruta $\mathrm{H}$, Arakawa K: Direct formation of angiotensin II without renin or converting enzyme in the ischemic dog heart. Jpn Heart J 1989; 30: 219229.

13. Haas E, Lewis L, Koshy TJ, Varde AU, Renerts L, Bagai, RC: Angiotensin II- producing enzyme III from acidified serum of nephrectomized dogs. Am J Physiol 1989; 2: 708-714.

14. Almeida JB, Saragoca MA, Tavares A, Cezareti ML, Draibe SA, Ramos OL: Severe hypertension induced disturbances of renal autoregulation. Hypertens 1992; 19 (suppl 2): II-279-II-283.

15. Hollenberg NK, Adams DF, Solomon H, et al: Renal vascular tone in essential and secondary hypertension: Hemodynamic and angiographic responses to vasodilators. Medicine 1975; 54: 29-44.

16. Hollenberg NK, Epstein M, Basch RI, Merrill JP: "No man's land" of the renal vasculature: an arteriographic and hemodynamic assessment of the interlobular and arcuate arteries in man in essential and accelerated hypertension. Am J Med 1969; 47: 845854.

17. Higa EMS, Rosenkranz A, Boim MA, et al: Renal hemodynamics in spontaneously hypertensive rats with superficial glomeruli. J Hypertens 1986; 4 (suppl 3): S379-S381. 
18. Iversen BM, Heyeraas $\mathrm{KJ}$, Seske I, Anderson $\mathrm{KJ}$, Ofstad J: Autoregulation of renal blood flow in twokidney, one clip hypertensive rats. Am J Physiol 1986; 251: F245-F250.

19. Iversen BM, Seske I, Ofstad J: Resetting of renal blood flow autoregulation in spontaneously hypertensive rats. Am J Physiol 1987; 252: F480-F486.

20. Hall JE, Guyton AC, Farr BM: A single-injection method for measuring glomerular filtration rate. $\mathrm{Am}$ J Physiol 1977; 232: F72-F76.

21. Chan DP, Sandok EK, Aarhus LL, Heublein DM, Burnett Jr. JC: Renal-specific actions of angiotensin II receptor antagonism in the anesthetized $\operatorname{dog}$. $A m \mathrm{~J}$
Hypertens 1992; 5: 354-360.

22. Dworkin LA, Brenner BM: The renal circulations, in Brenner BM, Rector FC (eds): The Kidney. Philadelphia, W.B. Saunders Co., 1991, pp 164-204.

23. Abe Y, Dixon F, McNay JI: Dissociation between autoregulation of renal blood flow and glomerular filtration rate. Am J Physiol 1970; 219: 986- 993.

24. Bovee KC, Wong PC, Timmermans PBMWM, Thoolen MJMC: Effect of the nonpeptide angiotensin II receptor antagonist DuP 753 on blood pressure and renal functions in spontaneously hypertensive $\mathrm{PH}$ dogs. Am J Hypertens 1991; 4: 327S-333S. 